\title{
RANCANG BANGUN SISTEM INFORMASI TOEFL PADA PUSAT BAHASA UNIVERSITAS MATARAM
}

\author{
(Toefl Information System Design in Language Center of University of Mataram)
}

\author{
Imam Tantowi, Moh. Ali Albar, Fitri Bimantoro \\ Program Studi teknik Informatika, Fakultas Teknik, Universitas Mataram \\ Jl. Majapahit 62, Mataram, Lombok NTB, INDONESIA \\ Email: imamtantowi585@gmail.com, mohalialbar@unram.ac.id, bimo@unram.ac.id
}

\begin{abstract}
This research was conducted based on existing problems in the registration system, scheduling, and announcement of the results of the TOEFL test at the Language Center of the University of Mataram. Where registration, scheduling, and the announcement of TOEFL test results are done manually which requires prospective participants to register directly at the language center of the University of Mataram. This system is expected to simplify the registration process, scheduling, displaying available quotas and checking TOEFL test results. This system was built using a Codelgniter framework, XAMPP as a web server and MySQL PhPMyadmin as its database server and built with the waterfall model as a system development method. This system is tested by the black box method and user interface testing will be used subjectively testing using the mean opinion score (MOS) by involving several respondents. Based on the test results of the Mean Opinion Score method, it can be concluded that $66.1 \%$ of the respondents agreed and $33 \%$ of the respondents strongly agreed with the TOEFL Information System Design in UNRAM.
\end{abstract}

Key words: TOEFL, web information system, MOS, BlackBox, waterfall method

*Penulis Korespondensi

\section{Pendahuluan}

Saat ini informasi mengenai Test of Foreign Language (TOEFL) di Pusat Bahasa Universitas Mataram (PUBAH UNRAM) masih berjalan secara manual mulai dari pendaftaran, penjadwalan, pembagian ruang ujian dan pengumuman hasil tes TOEFL yang hanya bisa dilihat di pusat bahasa Universitas Mataram yang tentunya akan membutuhkan lebih banyak waktu baik bagi peserta maupun petugas pusat bahasa. Berdasarkan permasalahan tersebut, penelitian yang dilakukan oleh peneliti adalah "Rancang Bangun Sistem Informasi TOEFL pada Pusat Bahasa Universitas Mataram (PUBAH UNRAM). Sistem informasi TOEFL pada PUBAH UNRAM ini nantinya diharapkan dapat memberikan kemudahan bagi peserta maupun pengelola dalam proses pelaksanaan TOEFL yang lebih efektif dan efisien di lingkunan Universitas Mataram. Peserta test tinggal mengakses website sistem informasi TOEFL untuk melakukan pendaftaran, mengetahui penjadwalan, pembagian ruang ujian dan melihat nilai hasil ujian tanpa harus datang ke PUBAH UNRAM. Rumusan fokus kajian pada penelitian ini adalah bagaimana membangun sebuah sistem informasi TOEFL yang menyediakan pelayanan mualai dari pendaftaran, penjadwalan sampai pengumuman hasil tes TOEFL

Sistem informasi TOEFL dibuat berbasis web menggunakan PHP-MySQL. Data yang digunakan adalah data data yang bersumber dari Pusat Bahasa Universitas Mataram. Sistem ini hanya menangani pada ruang lingkup kegiatan pelaksanaan TOEFL pada Pusat Bahasa Universitas Mataram. Sistem ini hanya menyediakan pelayanan pendaftaran, penjadwalan, riwayat daftar, Pembagian ruangan ujian dan pengumuman hasil ujian yang dapat di akses secara online. Tujuan penelitian ini membangun sistem informasi berbasis web yang akan menyediakan pelayanan pendaftaran, penjadwalan, pembagian ruang ujian dan pengumuman hasil tes TOEFL pada PUBAH UNRAM Untuk mengetahui pengimplementasian dari sistem informasi pendaftaran, penjadwalan, riwayat daftar, pembagian ruang ujian dan pengumuman hasil ujian TOEFL di PUBAH UNRAM. Manfaat dari penelitian ini adalah memudahkan pengelolaan data pendaftaran bagi sekertariat Pusat Bahasa dan memudahkan pendistribusian data baik itu data pendaftaran maupun laporan hasil ujian. 


\section{Tinjauan Pustaka}

Penelitian pembangunan sistem informasi untuk tes TOEFL dilakukan pada program studi Sistem Informasi Universitas Komputer Indonesia berbasis web dibangun untuk memudahkan pelayanan dan pelaksanaan tes TOEFL [1]. Penelitian ini bertujuan untuk membangun sebuah sistem informasi yang menyediakan pelayanan pendaftaran, penjadwalan, pelaksanaan tes dan proses validasi hasil tes TOEFL secara online pada Program studi Sistem Informasi Fakultas Teknik dan IImu Komputer Universitas Komputer Indonesia sehingga mempermudah mahasiswa untuk melakukan proses pendaftaran,dan proses validasi hasil tes TOEFL. Karena semua prosesnya akan dibuat secara online sehingga mahasiswa tidak perlu repot ke kampus untuk melakukan pendaftaran maupun untuk melihat hasil dari tes TOEFL yang sudah diikuti karena hasil tes akan langsung diketahui pada akhir tes tersebut.

Pada penelitian yang lain, UPT Bahasa Politeknik Negeri Cilacap menerapkan sistem scoring conversion TOEFL pada Paper Based Test. Pendekatan yang digunakan untuk membangun sistem ini adalah metode waterfal [2]. Tujuan dari penelitian ini untuk menyelesaikan permasalahan yang ada seperti proses pendaftaran penjadwalan dan pengumuman hasil tes TOEFL yang dapat di akses secara online. Selain itu terdapat beberapa fitur yang di sediakan pada sistem ini seperti konversi skor dan pembuatan sertifikat.

Penelitian lainnya terkait TOEFL adalah pembuatan Aplikasi sebagai sarana pelatihan bahasa inggris[3]. Aplikasi yang dibangun berbasis web dengan menggunakan metode Waterfall pada proses perancangannya. Pendekatan terstruktur digunakan dalam proses desain sistem ini. Fitur yang tersedia pada sistem ini adalah proses pendaftaran serta proses pelaksanaan tes TOEFL yang dapat dilakukan pada sistem ini dan diakses secara online serta menampilkan nilai hasil tes.

Penelitian lain yang berkaitan dengan sistem informasi TOEFL ini adalah penelitian dengan judul "TOEFL Online Berbasis Web" [4]. Penelitian ini bertujuan untuk mengembangkan sebuah sistem Test TOEFL online berbasis web dengan harapan dapat mendukung penyelenggaraan dan pelaksanaan test TOEFL yang sesuai denganstandar pelaksanaan test TOEFL.

Selain penelitian tersebut, terdapat juga penelitian yang melakkukan perancangan dan implementasi aplikasi TOEFL dan TPA dengan pendekatan metode waterfall [5]. Tujuan dari penelitian ini untuk menghasilkan sebuah aplikasi berbasis online yang dapat menunjang pelaksanaan tes TOEFL dan TPA pada perguruan tinggi.

\section{Metode Penelitian}

\subsection{Alat dan Bahan}

Alat-alat yang digunakan dalam pembangunan sistem informasi TOEFL ini dapat dirincikan sebagai berikut :

1. Laptop dengan processor Intel ${ }^{\circledR}$ Core (TM) I32330M CPU (2. ), RAM 4 GB GB.

2. Windows 10 64-bit sebagai sistem operasi.

3. Framework codeigniter dan sublime text untuk membangun sistem.

4. Xampp untuk membangun jaringan lokal pada satu laptop.

5. PHP dan HTML sebagai bahasa pemrogramannya.

6. Bootstrap sebagai template antarmuka sistem yang akan dibangun

7. MySQL sebagai server database-nya,

Bahan-bahan yang digunakan dalam pembangunan sistem ini dapat dirincikan sebagai berikut :

1. Data formulir pendaftaran tes TOEFL pada pusat bahasa Universitas Mataram.

2. Data hasil tes dan bentuk pengumuman yang didapat dari pusat bahasa.

\subsection{Metode pengembangan sistem}

Metode waterfall digunakan sebagai dasar pengembangan sistem yang akan dibangun. Metode waterfall memungkinkan pengerjaan sistem yang dilkaukan secara linear atau secara berurutan [6]. Setiap langkah-langkah pengerjaan harus dikerjakan berurutan tanpa bisa dilewati. Apabila langkah pertama belum dikerjakan, maka sangat tidak memungkinkan untuk mengerjakan langkah selanjutnya. Sehingga untuk menyelesaikan pengembangan sistem, sebuah keharusan bahwa penyelesaian setiap langkah pekerjaan harus diselesaikan dengan tuntas. Tahapan metode waterfall dapat dilihat pada Gambar 1. 


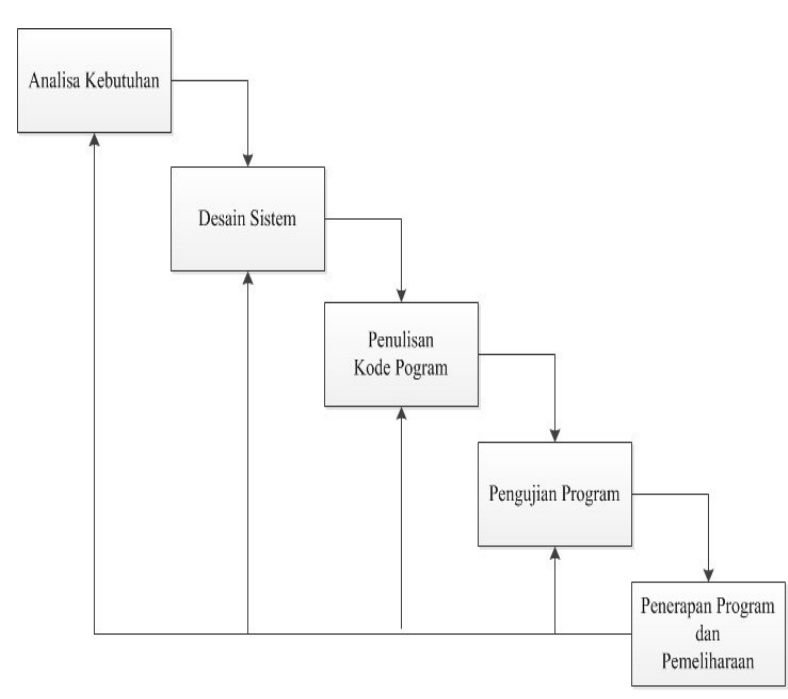

Gambar 1. Metode Waterfall

\subsection{Diagram Alir Penelitian}

Pada penelitian ini dilakukan beberapa tahapan untuk mendapatkan hasil yang sesuai dengan yang diharapkan, Gambar 2 menyajikan diagram alir penelitian

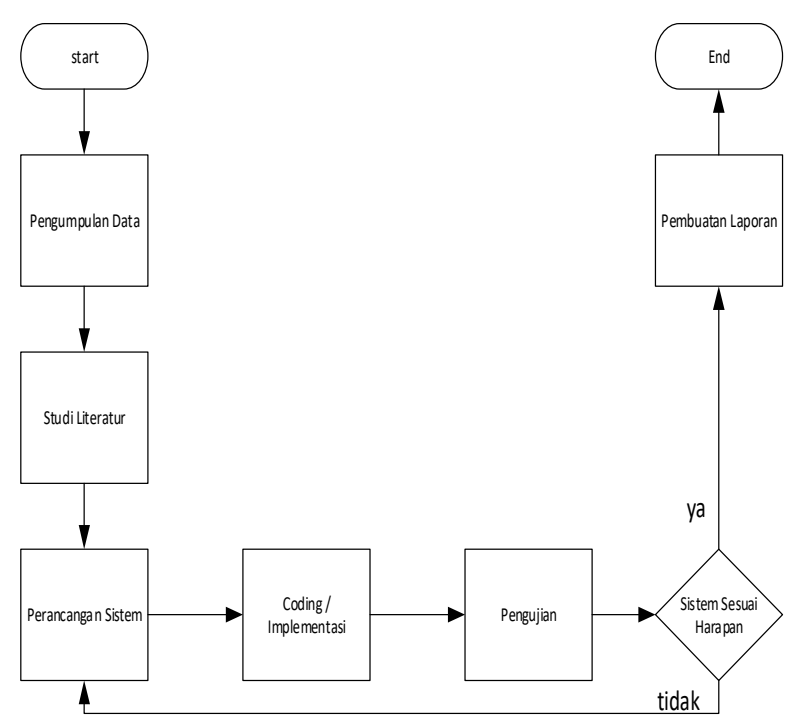

Gambar 2. Diagram alir penelitian

\subsection{Perancangan sistem}

\subsubsection{Usecase diagram}

Pada tahap ini, bentuk penggambaran fungsionalitas dari setiap pengguna dalam menjalankan sistem divisualisasikan[7]. Terdapat 2 actor yang terlibat dalam usecase diagram sistem informasi TOEFL yaitu calon peserta dan admin pusat bahasa. Perancangan usecase diagram seperti pada Gambar 3.

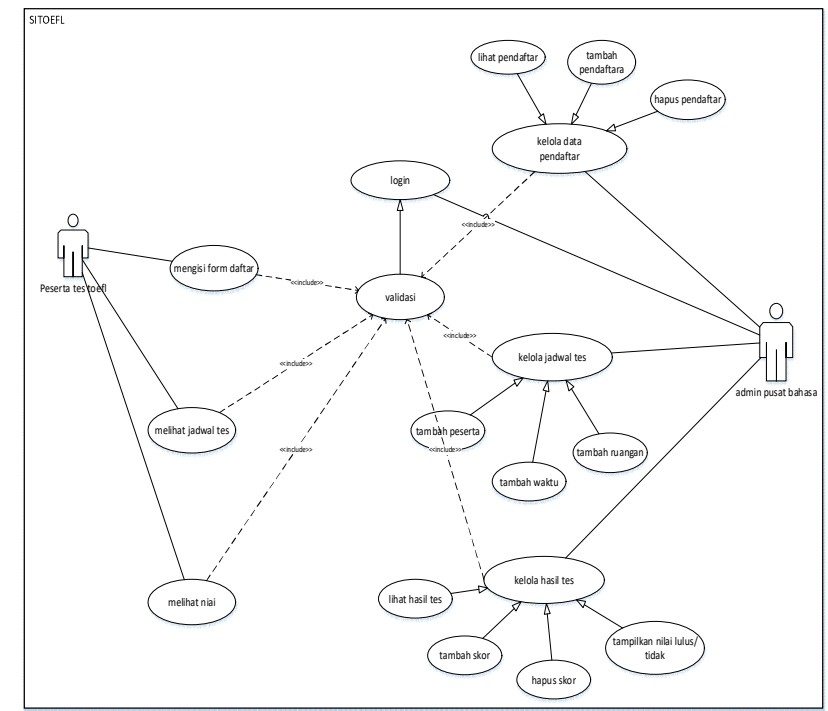

Gambar 3. Usecase Diagram

\subsubsection{ERD (Entity Relationship Diagram)}

ERD menggambarkan hubungan relasi antar tabel [8]. Beberapa tabel yang saling berelasi pada sistem ini antara lain table pendaftar, admin, peserta tes, ruangandan nilai. Rancangan ERD dalpat dilihat pada Gambar 4.

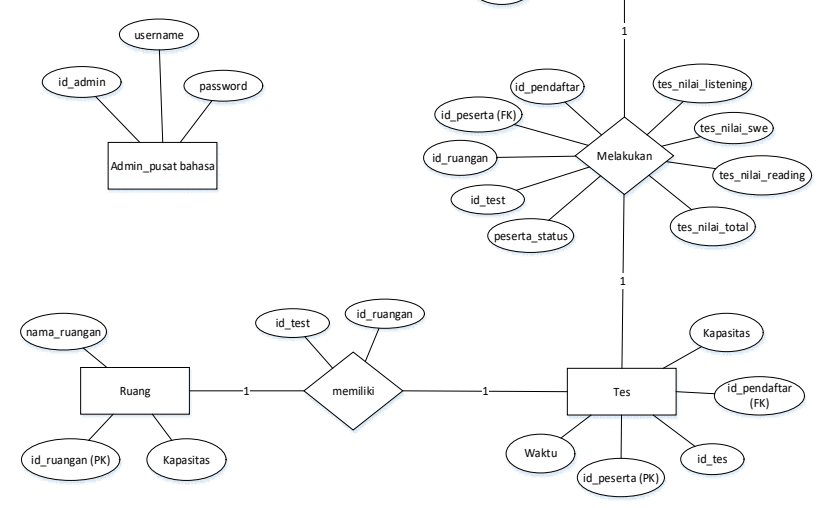

Gambar 4. Rancangan ERD

\subsection{Metode pengujian sistem}

Pada tahap ini informasi akan diuji apakah sistem dapat membantu peserta TOEFL dan staff pusat bahasa dalam memudahkan pelayanan tes TOEFL mulai dari proses registrasi sampai pengumuman hasil tes TOEFL . Sistem akan diuji dari aspek fungsionalitas dengan menggunakan metode black box. Penggunaan metode black box bertujuan untuk menguji fungsionalitas dari 
masing-masing fitur yang ada pada sistem, apakah fitur sudah berjalan sebagaimana mestinya atau tidak [9]. Untuk pengujian user interface akan digunakan pengujian secara subjektif dengan menggunakan Mean Opinion Score (MOS). Metode Mean Opinion Score (MOS) dilakukan dengan mengumpulkan penilaian kualitatif secara visual secara subjektif [10]. Penilain dilakukan dengan melakukan pengamatan secara visual dari masing-masing koresponden yang dilibatkan. Pada pengujian sistem ini melibatkan 30 responden mulai dari mahasiswa UNRAM, dan orang umum .

\section{HaSil dan Pembahasan}

Berikut ini merupakan hasil dan pembahasan dalam "Sistem Informasi TOEFL pada PUBAH UNRAM". Seperti yang telah dipaparkan sebelumnya, yaitu mengenai langkah-langkah pengerjaan yang dilakukan dalam pembuatan sistem informasi TOEFL. Pembahasan secara terperinci mengenai pengimplementasian Sistem Informasi TOEFL pada PUBAH UNRAM.

\subsection{Implementasi alur kerja sistem}

\subsubsection{Halaman Home Peserta Tes TOEFL}

Pada halaman ini terdapat beberapa fitur diantaranya, menu daftar, cetak kartu peserta dan cek hasil. Selain itu user juga dapat melihat tata cara pendaftaran yang sudah di sediakan pada sistem ini. Halaman home peserta dapat dilihat pada Gambar 5.

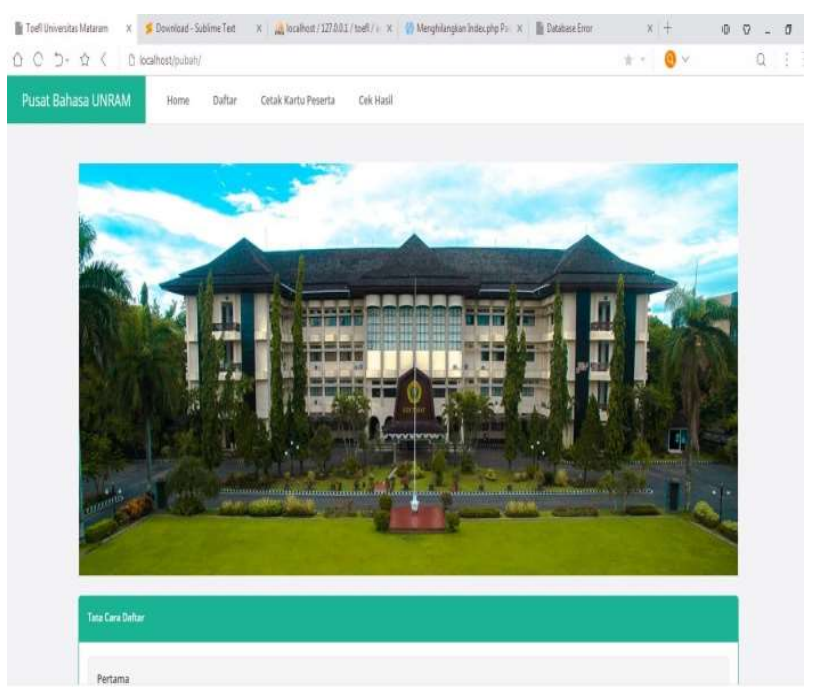

Gambar 5. Halaman home untuk peserta tes TOEFL

\subsubsection{Halaman Daftar}

Pada halaman ini user dapat melakukan pengecekan status seagai pendaftar apakah sudah di verifikasi atau belum di verifikasi oleh admin Pusat Bahasa, dengan memasukkan id Pendaftar yang sudah di berikan pada form yang tersedia pada sistem. Halaman cek status pendaftar dapat dilihat pada Gambar 6.



Gambar 6. Cek status pendaftar

Untuk user yang belum melakukan pendaftaran, dapat memilih menu daftar yang menyediakan form untuk pengisian data-data yang harus diisi secara lengkap. Setelah mengisi data-data yang di perlukan, pendaftar disarankan mencatat Id pendaftar yang akan muncul pada popup notifikasi setelah melakukan penyimpanan data pendaftar pada form daftar. Halaman form daftar dan popup notifikasi daftar berhasil dapat dilihat pada Gambar 7 dan Gambar 8.

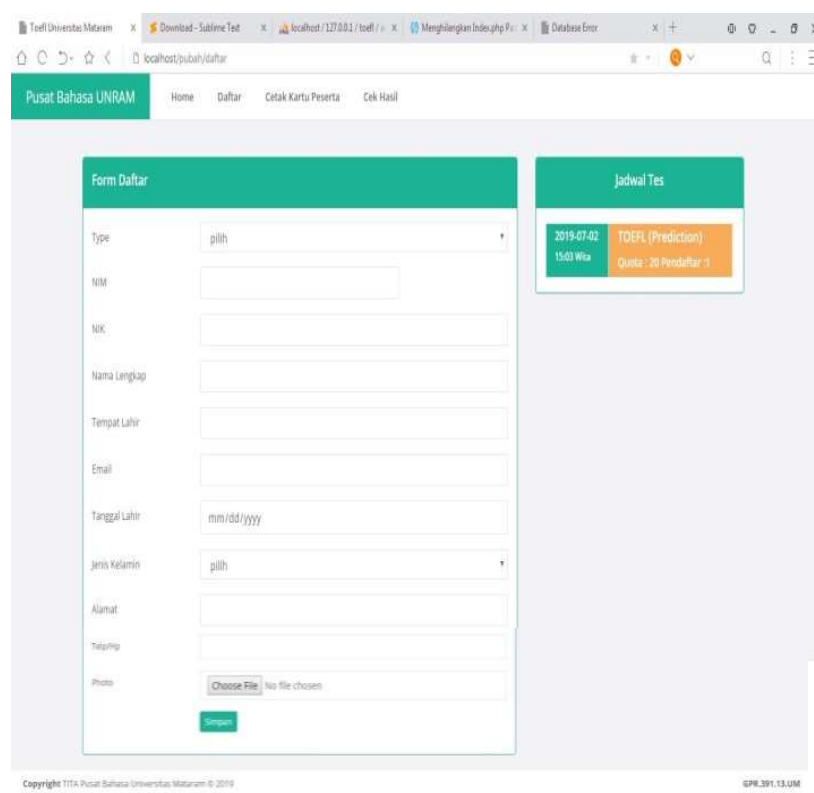

Gambar 7. Halaman form daftar 


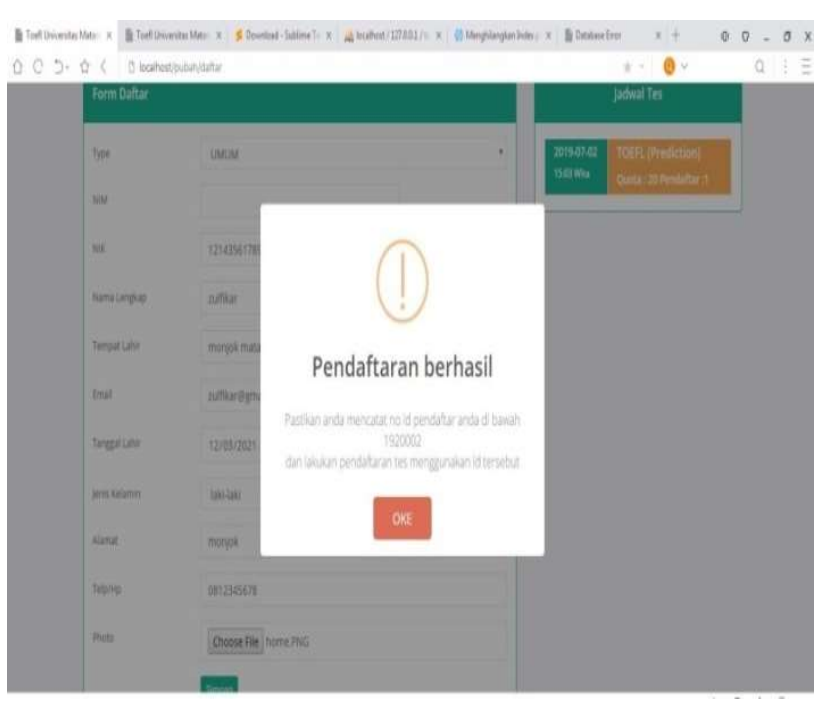

Gambar 8. Popup daftar berhasil

\subsubsection{Halaman Cetak kartu}

Apabila pendaftar sudah melakukan pembayaran dan di verifikasi oleh admin serta sudah mempunyai jadwal tes, maka calon peserta dapat mecetak langsung kartu peserta pada sistem dengan memasukkan id_pendaftar, tanggal lahir dan tanggal tes pada form yang di sediakan. Halaman cetak kartu peserta dapat dilihat pada Gamar 9.



Gambar 9. Form cetak kartu

\subsubsection{Halaman Tampilan Kartu Peserta}

Pada halaman ini akan muncul tampilan kartu peserta sesuai dengan data-data yang di masukkan pada saat mengisi form pendaftaran. Apabila sudah sesuai maka pendaftar dapat mencetak langsung kartu peserta. Halaman tampilan kartu peserta dapat dilihat pada Gambar 10.

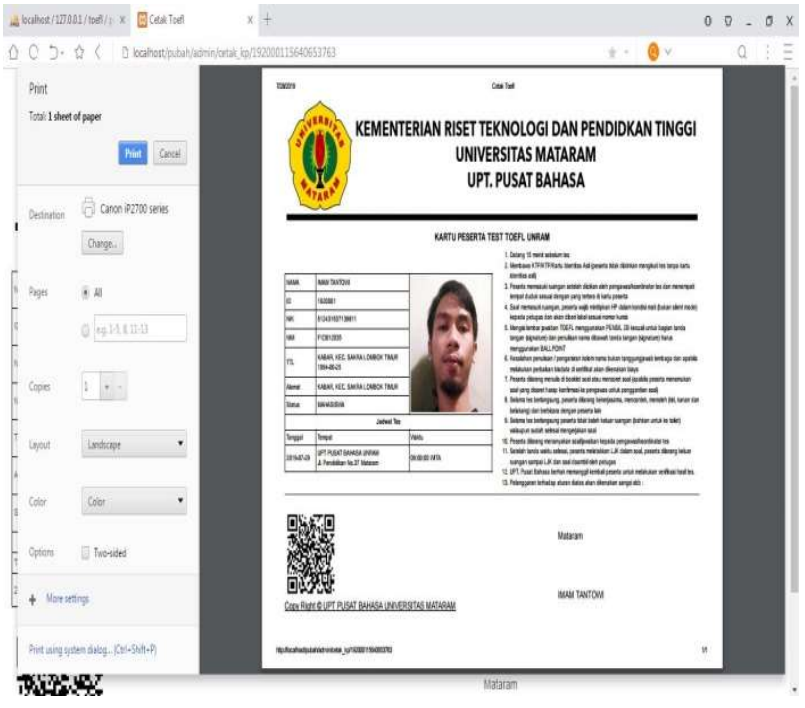

Gambar 10. Tampilan kartu peserta

\subsubsection{Halaman Tampilan cek hasil}

Pada halaman ini peserta tes yang sudah melaksanakan tes TOEFL dapat melihat hasill atau nilai yang diperoleh, dengan memasukkan id peserta, tanggal lahirdan taggal test pada form yang tersedia pada sistem. Halaman tampilan cek hasil dapat dilihat pada gambar 11.

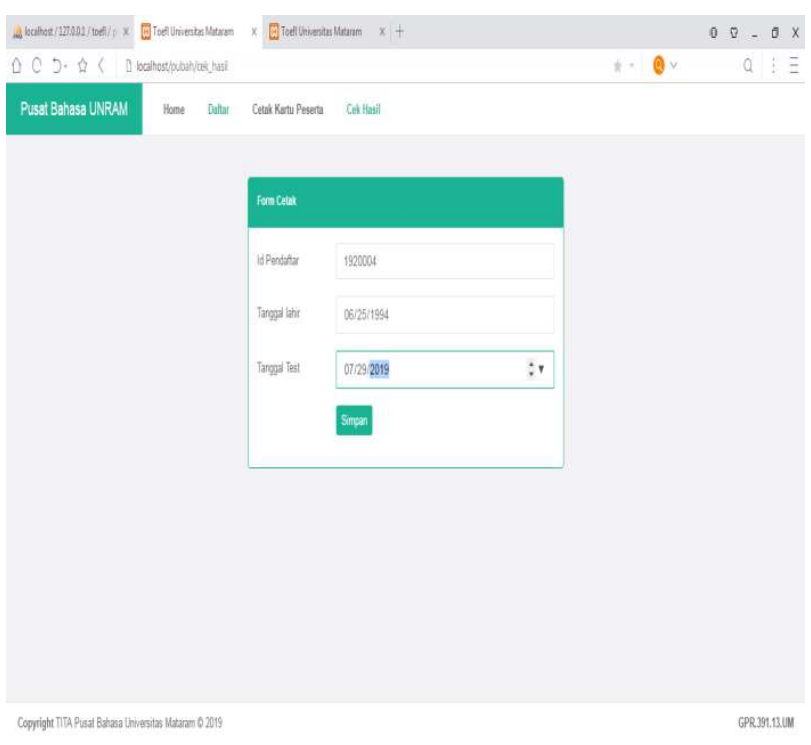

Gambar 11. Form cek hasil

\subsubsection{Hasil Pengujian Black Box}

Pada pengujian dengan metode black box dimana metode pengujian ini dilakukan untuk menguji fiturfitur atau fungsi-fungsi yang tersedia pada sistem untuk menentukan apakah layanan atau fungsi atau fitur tersebut sudah berjalan sebagaimana mestinya atau tidak. Berikut merupakan beberapa fungsi-fungsi 
pada sistem informasi TOEFL pada PUBAH UNRAM yang akan diuji menggunakan metode black box, yaitu:

1. Fungsi Login Admininstrator. Pengujian pada fitur fungsi login administrator dilakukan untuk menguji apakah fungsi yang berjalan pada halaman login admin sudah berfungsi dengan baik dan benar pada pengujian fungsi login Admininstrator terdapat 3 skenario pengujian.

TABEL I. PENGUJIAN FUNGSI LOGIN ADMINISTRATOR

\begin{tabular}{|c|c|c|c|}
\hline $\begin{array}{c}\text { Skenario } \\
\text { Pengujian }\end{array}$ & $\begin{array}{c}\text { Hasil yang } \\
\text { Diharapkan }\end{array}$ & $\begin{array}{c}\text { Hasil } \\
\text { Pengujian }\end{array}$ & Kesimpulan \\
\hline $\begin{array}{c}\text { Form username } \\
\text { dan password di isi } \\
\text { menggunakan } \\
\text { data yang tidak } \\
\text { sesuai }\end{array}$ & $\begin{array}{c}\text { Proses login } \\
\text { tidak berhasil } \\
\text { dan akan } \\
\text { merujuk ke } \\
\text { halaman login } \\
\text { admin }\end{array}$ & Sesuai & Valid \\
\hline $\begin{array}{c}\text { Form username } \\
\text { dan password di isi } \\
\text { menggunakan } \\
\text { data yang benar. }\end{array}$ & $\begin{array}{c}\text { Proses login } \\
\text { berhasil admin } \\
\text { dirujuk ke } \\
\text { halaman admin. }\end{array}$ & Sesuai & Valid \\
\hline
\end{tabular}

2. Fungsi Proses Simpan Form Daftar. Fungsi pada proses simpan form daftar merupakan fungsi yang dilakukan oleh pendaftar ketika mengisi data-data pribadi pada form daftar yang sudah di sediakan pada sistem informasi TOEFL (lihat Tabel II).

TABEL II. PENGUJIAN FUNGSI SIMPAN FORM DAFTAR

\begin{tabular}{|c|c|c|c|}
\hline $\begin{array}{l}\text { Skenario } \\
\text { Pengujian }\end{array}$ & $\begin{array}{l}\text { Hasil yang } \\
\text { Diharapkan }\end{array}$ & $\begin{array}{c}\text { Hasil } \\
\text { Penguji } \\
\text { an }\end{array}$ & $\begin{array}{c}\text { Kesi } \\
\text { mpul } \\
\text { an }\end{array}$ \\
\hline $\begin{array}{l}\text { Salah satu atau } \\
\text { lebih form } \\
\text { daftar } \\
\text { dikosongkan } \\
\text { kemudian } \\
\text { button simpan } \\
\text { dipilih. }\end{array}$ & $\begin{array}{l}\text { Proses } \\
\text { penyimpanan } \\
\text { gagal, ada } \\
\text { notifikasi untuk } \\
\text { mengisi form } \\
\text { yang kosong. }\end{array}$ & Sesuai & Valid \\
\hline $\begin{array}{l}\text { Seluruh form } \\
\text { pada laman } \\
\text { daftar diisi } \\
\text { dengan } \\
\text { lengkap, } \\
\text { kemudian } \\
\text { button simpan } \\
\text { dipilih. }\end{array}$ & $\begin{array}{l}\text { Proses simpan } \\
\text { data pada form } \\
\text { daftar berhasil } \\
\text { dan datanya } \\
\text { berhasil } \\
\text { tersimpan dalam } \\
\text { database. }\end{array}$ & Sesuai & Valid \\
\hline
\end{tabular}

3. Fungsi pada Proses Cetak Kartu Peserta . Pada fungsi ini,calon peserta yang sudah menyelesikan daftar tes melakukan cetak kartu tes dengan mengisi form cetak kartu tes yang ada pada sistem informasi TOEFL(lihat Tabel III).

TABel III. Pengujian pada proses Cetak kartu tes

\begin{tabular}{|c|c|c|c|}
\hline $\begin{array}{c}\text { Skenario } \\
\text { Pengujian }\end{array}$ & $\begin{array}{c}\text { Hasil yang } \\
\text { Diharapkan }\end{array}$ & $\begin{array}{c}\text { Hasil } \\
\text { Pengujian }\end{array}$ & $\begin{array}{c}\text { Kesimp } \\
\text { ulan }\end{array}$ \\
\hline $\begin{array}{l}\text { Salah satu atau } \\
\text { lebih form } \\
\text { cetak } \\
\text { dikosongkan } \\
\text { kemudian } \\
\text { button simpan } \\
\text { dipilih. }\end{array}$ & $\begin{array}{l}\text { Proses cetak } \\
\text { kartu gagal, } \\
\text { ada notifikasi } \\
\text { untuk mengisi } \\
\text { form yang } \\
\text { kosong. }\end{array}$ & Sesuai & Valid \\
\hline $\begin{array}{l}\text { Seluruh form } \\
\text { pada laman } \\
\text { cetak kartu } \\
\text { peserta diisi } \\
\text { dengan } \\
\text { lengkap, } \\
\text { kemudian } \\
\text { button simpan } \\
\text { dipilih. }\end{array}$ & $\begin{array}{l}\text { Proses cetak } \\
\text { kartu berhasil, } \\
\text { dan beralih ke } \\
\text { halaman } \\
\text { tampilan kartu } \\
\text { peserta.. }\end{array}$ & Sesuai & Valid \\
\hline
\end{tabular}

4. Fungsi Proses Cek hasil (lihat Tabel IV). Fungsi cek hasil merupakan fungsi untuk melihat hasil tes yang di ikuti oleh peserta tes TOEFL dengan memasukkan data pada form cek hasil yang disediakan pada sistem informasi TOEFL.

TABel IV. PenguJIAN FUNGSI CEK HASIL

\begin{tabular}{|l|l|c|c|}
\hline \multicolumn{1}{|c|}{$\begin{array}{c}\text { Skenario } \\
\text { Pengujian }\end{array}$} & $\begin{array}{c}\text { Hasil yang } \\
\text { Diharapkan }\end{array}$ & $\begin{array}{c}\text { Hasil } \\
\text { Pengujian }\end{array}$ & $\begin{array}{c}\text { Kesim } \\
\text { pulan }\end{array}$ \\
\hline $\begin{array}{l}\text { form cek hasil } \\
\text { dikosongkan } \\
\text { dan button } \\
\text { simpan } \\
\text { dipilih. }\end{array}$ & $\begin{array}{l}\text { Proses untuk } \\
\text { cek hasil tidak } \\
\text { dapat } \\
\text { dilakukan, ada } \\
\text { notifikasi untuk } \\
\text { mengisi form } \\
\text { yang kosong. }\end{array}$ & Sesuai & Valid \\
\hline $\begin{array}{l}\text { form pada } \\
\text { laman cek } \\
\text { hasil diisi } \\
\text { dengan } \\
\text { lengka,button } \\
\text { simpan } \\
\text { dipilih. }\end{array}$ & $\begin{array}{l}\text { Proses cek hasil } \\
\text { berhasil, dan } \\
\text { beralih ke } \\
\text { halaman } \\
\text { tampilan hasil } \\
\text { tes.. }\end{array}$ & Sesuai & Valid \\
\hline
\end{tabular}

\subsubsection{Hasil Pengujian Kuesioner dengan Metode Mean Opinion Score (MOS).}

Setelah dilakukan pengujian kuesioner yang melibatkan 30 koresponden, didapatkan hasil sebanyak 117 pernyataan setuju atau rata-rata persentase yang didapat adalah $66.1 \%$, dan 60 jumlah 
pernyataan sangat setuju atau rata-rata persentase yang didapat adalah 33,9\% dari 6 pertanyaan yang diajukan pada kuesioner.

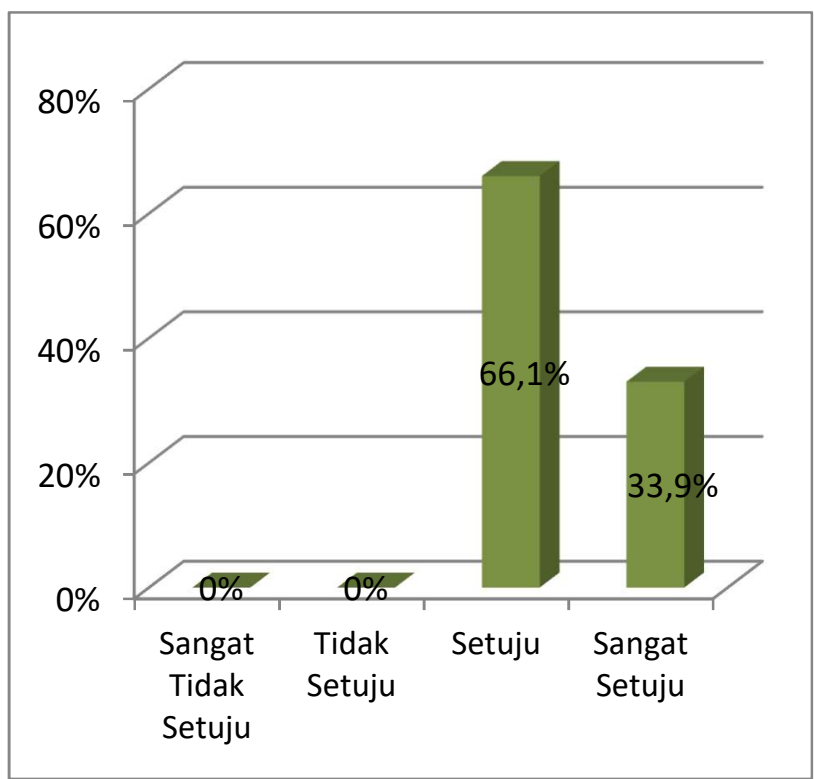

Gambar 12.G rafik rata-rata pernyataan responden.

Berdasarkan hasil yang diperoleh, didapat kesimpulan bahwa sistem ini memiliki desain tampilan interface yang menarik, selain itu hasil yang ditampilkan sudah sesuai dengan keinginan, sistem ini dapat membatu setiap calon peserta melakukan pendaftaran tes TOEFL. Sistem ini dapat membatu setiap peserta melihat hasil tes TOEFL, dapat membantu admin mengelola data pendaftar tes TOEFL dan sistem ini dapat digunakan pada PUBAH UNRAM.

\section{KESIMPULAN DAN SARAN}

\subsection{Kesimpulan}

Berdasarkan hasil penelitian dan pembuatan sistem yang telah dilakukan, maka didapatkan beberapa kesimpulan sebagai berikut :

1. Rancang Bangun Sistem TOEFL ini mengambil studi kasus pada PUBAH UNRAM dengan pokok permasalahan yaitu, pelayanan daftar tes dan cek hasil tes. Pada sistem ini calon peserta dapat melakukan registrasi tes TOEFL secara online. Selain itu peserta yang telah mengikuti tes TOEFL juga dapat melihat hasil tes pada sistem ini.

2. Pada sisem ini admin PUBAH UNRAM dapat mengelola data pendaftar dan peserta tes yang akan mengikuti tes TOEFL serta dapat menampilkan hasil dari tes TOEFL yang yang diikuti oleh para peserta.
3. Hasil pengujian dengan metode black box seluruh fungsi telah berjalan sebagai mana mestinya dengan sistem sesuai yang diharapkan oleh pengguna system, khususnya calon peserta tes TOEFL dan admin PUBAH UNRAM.

4. Berdasarkan hasil pengujian metode MOS dapat disimpulkan bahwa sebesar 66,1\% responden menyatakan setuju dan sebesar $33 \%$ responden menyatakan sangat setuju dengan Rancang Bangun Sistem Informasi TOEFL pada PUBAH UNRAM.

\subsection{Saran}

Karena masih banyaknya kekurangan dari penulis dalam mengembangkan sistem ini, terdapat beberapa saran untuk dapat membuat sistem ini menjadi lebih baik pada waktu yang akan datang diantaranya :

1. Sistem informasi TOEFL pada PUBAH UNRAM ini belum memiliki layanan untuk tes secara online, jadi diharapkan kedepannya dapat dikembangkan sehingga sistem ini dapat memiliki fitur untuk tes online yang mendukung pelayanan TOEFL menjadi lebih efektif.

2. Diharapkan kedepannya sistem informasi TOEFL pada PUBAH UNRAM dapat dikembangkan ke versi mobile agar pengguna lebih mudah dan praktis dalam mengakses sistem ini.

\section{DAFTAR PUSTAKa}

[1] S. R. Graitasadu, "Sistem Informasi Pelayanan Dan Pelaksanaan Tes Toefl Berbasis Website Pada Program Studi Sistem Informasi Universitas Komputer Indonesia," 10512214, 2017.

[2] C. Vikasari, "Sistem Scoring Conversion TOEFL Studi Kasus Unit Pelaksana Teknis Bahasa Politeknik Negeri Cilacap," 2017.

[3] Y. Y. Marbun et al., "Pembuatan Aplikasi Toefl Sebagai Media Pelatihan Bahasa," Teknol. dan Sist. Komput., vol. 4, no. 1, pp. 83-92, 2016.

[4] M. G. Rohman, "Toefl Online Berbasis Web," vol. 8, no. 1, pp. 781-790, 2016.

[5] M.R. U.Sugiri, "Perancangan Dan Implementasi Aplikasi Toefl (Test Of English As Foreign Language) Dan Tpa (Tes Potensi Akademik) Berbasis Web Untuk Perguruan Tinggi," Informasi, vol. VII, no. 1, pp. 84-100, 2015.

[6] Y. Utama, "Sistem_Informasi_Berbasis_Web," Sist. Inf. Berbas. Web Jur. Sist. Inf. Fak. IImu Komput. Univ. Sriwij., vol. 3, pp. 359-370, 2011.

[7] T. A. Kurniawan, "Pemodelan Use Case (UML): Evaluasi Terhadap beberapa Kesalahan dalam Praktik," J. Teknol. Inf. dan IImu Komput., vol. 5, 
no. 1, p. 77, 2018.

[8] Y. F. dan J. Waterkamp, "Jurnal Sistem Informasi ( Journal of Information Systems ). 2 / 13 ( 2017 ), 103-109 DOI : http://dx.doi.org/10.21609/jsi.v13i2.545,"

Anal. Dan Perenc. Strateg. Sist. Dan Teknol. Inf. Menggunakan Balanc. Scorec. Pada Inst. Bisnis Dan Inform. Kwik Kian Gie, vol. 13, pp. 103-109, 2017.

[9] M. S. Mustaqbal, R. F. Firdaus, and H. Rahmadi, "Pengujian Aplikasi Menggunakan Black box Testing Boundary Value Analysis (Studi Kasus :
Aplikasi Prediksi Kelulusan Snmptn)," Penguji. Apl. Menggunakan Black Box Test. Bound. Value Anal. (Studi Kasus Apl. Prediksi Kelulusan SNMPTN), vol. I, no. 3, p. 34, 2015.

[10] R. Fitriyanti, L. Lindawati, and A. Aryanti, "Analisis Perbandingan Mean Opinion Score Aplikasi VolP Facebook Messenger dan Google Hangouts menggunakan Metode E-Model pada Jaringan LTE," ELKOMIKA J. Tek. Energi Elektr. Tek. Telekomun. Tek. Elektron., vol. 6, no. 3, p. 379, 2018. 